\title{
Serum amphiregulin and cerebellin 1 levels in primary hypertension patients
}

\author{
Özlem Güler $\odot^{1}$, Hakan Hakkoymaz ${ }^{1}$, Sedat Köroğlu $\oplus^{2}$, Muhammed Seyithanoğlu $\odot^{3}$, Hakan Güneş $\odot^{4}$ \\ 'Department of Emergency Medicine, Kahramanmaraş Sütçü Imam University School of Medicine, Kahramanmaraş, Turkey \\ ${ }^{2}$ Department of Cardiology, Kahramanmaraş Necip Fazıl State Hospital, Kahramanmaraş, Turkey \\ ${ }^{3}$ Department of Biochemistry, Kahramanmaraş Sütçü Imam University School of Medicine, Kahramanmaraş, Turkey \\ ${ }^{4}$ Department of Cardiology, Kahramanmaraş Sütçü Imam University School of Medicine, Kahramanmaraş, Turkey
}

\begin{abstract}
Background: Hypertension is a major risk factor for cardiovascular diseases, stroke, congestive heart disease and renal failure. Primary hypertension is a multi-factorial complex disease and its exact etiology still remains unknown. In this study we aimed to compare serum amphiregulin and cerebellin-1 levels of primary hypertension patients with healthy subjects.

Material and methods: Forty-four hypertensive patients and 44 healthy people were included. Patients with systolic blood pressure measurements $\geq 140 \mathrm{~mm} \mathrm{Hg}$ and diastolic blood pressure measurements $\geq 90 \mathrm{~mm} \mathrm{Hg}$ were evaluated as hypertensive. Serum amphiregulin and cerebellin 1 levels were measured using ELISA method.

Results: Mean amphiregulin level was $32.1(10.2-72.5) \mathrm{pg} / \mathrm{mL}$ in hypertension group and 36.9 (15.9-109.5) $\mathrm{pg} / \mathrm{mL}$ in control group $(\mathrm{p}=0.002)$. Mean cerebellin 1 levels were comparable in both groups, 82.1 (23.9-286.1) $\mathrm{pg} / \mathrm{mL}$ in hypertensive group and $95.1(60.2-293) \mathrm{pg} / \mathrm{mL}$ in control group $(\mathrm{p}=0.261)$. Serum amphiregulin to predict hypertension was found to be $\leq 23 \mathrm{pg} / \mathrm{mL}$ with specificity of $97 \%$ and sensitivity of $48.5 \%$ (AUC $=0.74$; 95\% CI, 0.62-0.86; $\mathrm{p}=0.001$ ).

Conclusions: Hypertension is associated with lower serum amphiregulin concentrations.
\end{abstract}

Key words: amphiregulin; cerebellin 1; primary hypertension; ELISA

Arterial Hypertens. 2020, vol. 24, no. 3, pages: 120-127

DOI: 10.5603/AH.a2020.0015

\section{Introduction}

Hypertension is a major risk factor for cardiovascular diseases, stroke, congestive heart disease and renal failure [1]. Primary hypertension affecting approximately $95 \%$ of all cases is a multifactorial complex disease and its exact etiology still remains unknown. Genetic and environmental stimuli and their interactions are thought to determine the disease [2]. It is estimated that over 1 billion people have been affected by primary hypertension [3]. Up to $54 \%$ of stroke and $47 \%$ of ischemic heart disease may be attributed to high blood pressure worldwide [1].

Amphiregulin is a protein which acts as a ligand for epidermal growth factor (EGF) [4]. Epidermal growth factor is detectable in the serum of healthy individuals, as well as many other organs including: placenta, ovaries, testes, heart, pancreas, spleen, bone marrow, kidneys, lungs, colon and breasts $[4,5]$. It has been shown that EGF can play a role in blood pressure regulation and deteriorate endothelial function $[6,7]$.

Address for correspondence: Assistant Prof. Dr. Özlem Güler, Kahramanmaraş Sütçü İmam University, School of Medicine, Department of Emergency Medicine, Kahramanmaraş Sütçü İmam Üniversitesi Rektörlüğü, Avşar Mah. Batı Çevreyolu Blv. No: 251/A 46040, Onikişubat/Kahramanmaraş, tel: (+90) 0533771 4080, fax: (+90) (344) 30010 37; e-mail: ozlemguler81@yahoo.com 
Cerebellin is derived from precerebellin and has neuromodulatory functions such as maintaining of synaptic structures and modulating of their functions in the brain [8]. It has been determined that cerebellin is secreted from adrenal glands, neuroendocrine system and pancreas [9-12]. Cerebellin has a stimulating effect on the secretion of aldosterone, cortisol and catecholamine from the adrenal glands and this may contribute to an increase in blood pressure [13].

To the best of our knowledge the interplay between cerebellin, amphiregulin in primary hypertension was scarcely investigated.

\section{Material and methods}

The study followed the tenets of the Declaration of Helsinki and was approved by the institutional ethics committee (approval number: 2017/20/18) and informed consent was obtained from all of the participants. 102 patients who were admitted to the Emergency Department of Kahramanmaraş Sütçü İmam University Faculty of Medicine between January 2019 and December 2019 with headache and elevated arterial blood pressure older than 18 years of age were included in the study. Physical examination and arterial pressure measurements of these patients were performed. Arterial blood pressure was measured using a suitable cuff after resting the patients in a physically available quiet room for 5 minutes. A special attention was paid to that the patients did not drink cigarettes, tea, coffee or eat in the last 30 minutes. The average of two or more office measurements obtained on two or more occasions of 140/90 $\mathrm{mm} \mathrm{Hg}$ and above was defined as hypertension [14-16]. Patients with cerebrovascular event, previously diagnosed hypertension patients, antihypertensive drug users were excluded. Patients who were obese or diagnosed with diabetes, Cushing syndrome, rheumatologic disease, chronic headache, migraine, intracranial mass, acute and chronic renal failure and active infection were also excluded from the study. After applying the exclusion criteria listed above, 55 of 102 patients were referred to the cardiologist for further evaluation. Secondary hypertension (renal parenchymal disease, renovascular disease, primary aldosteronism, hyperthyroidism, hypothyroidism, hyperparathyroidism, pheochromocytoma, coarctation of the aorta, drug-induced hypertension and etc.) and white coat hypertension were ruled out. Echocardiographic evaluation was performed in all hypertensive patients. End-organ damage was investigated and routine laboratory values of the patients were examined. Finally forty-four newly diagnosed hypertension patients without end-organ damage were included in the study (Fig. 1). As the control group, 44 healthy volunteers with similar age and sex who presented to the outpatient clinic were

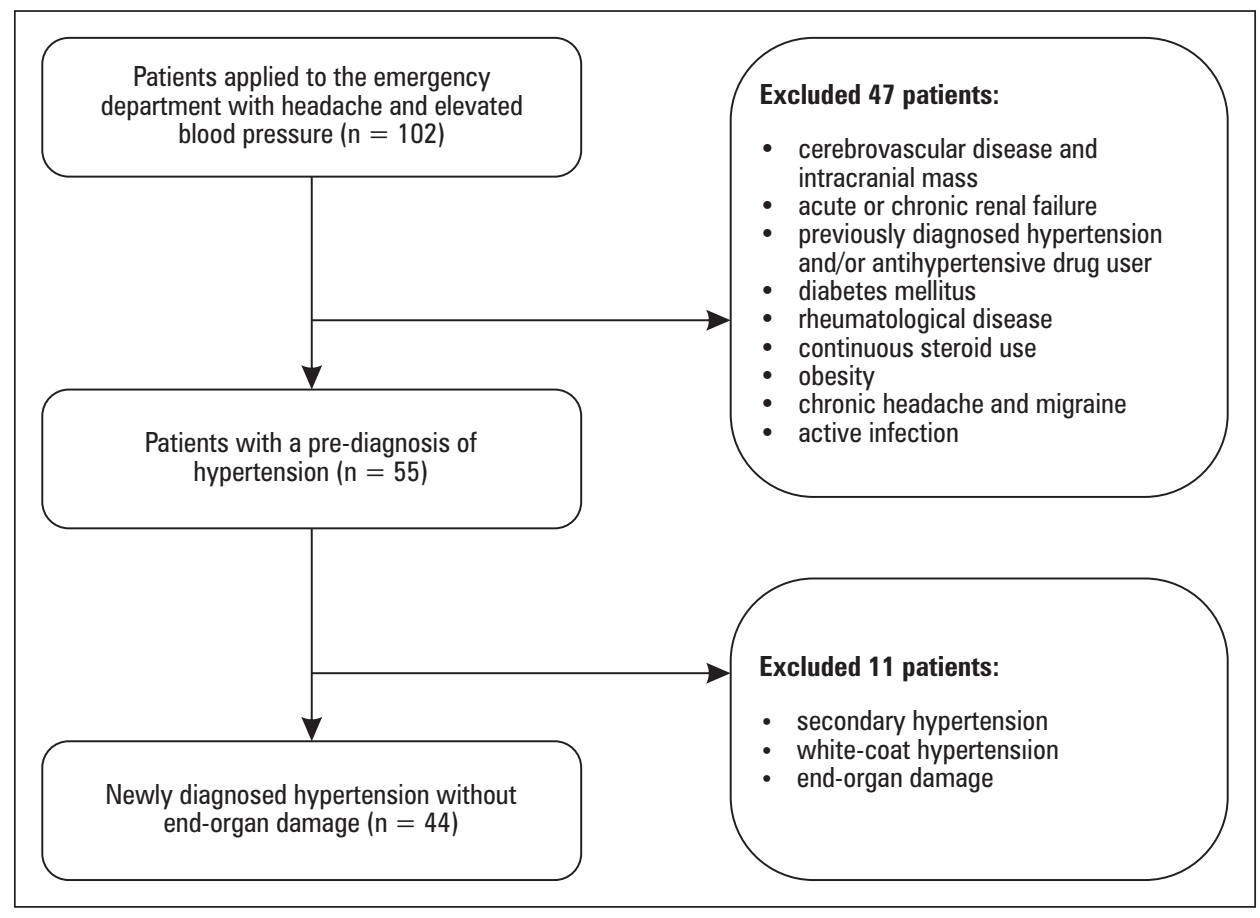

Figure 1. Flow chart shows the patient selection process 
included in the study. Blood samples were collected and centrifuged at $4000 \mathrm{~g}$ for 10 minutes. The serum samples were collected and stored at $-80^{\circ} \mathrm{C}$ until required for analysis.

Transthoracic echocardiographic examinations were performed by experienced echocardiographers who were blinded about the clinical information of the subjects via the Vivid $7^{\circ}$ cardiac ultrasonography system (GE Ving-Med Ultrasound AS; Horten, Norway) with 2.5- to 5-MHz probes. The supine and left lateral positions were conducted for each patient with 2D, M-mode, pulsed and color flow Doppler echocardiography. Single lead electrocardiogram continuously recorded. For all measurements, the average of at least three cardiac cycles was evaluated. For the conventional Doppler echocardiographic examinations and M-mode measurements, the European Society of Echocardiography guideline criteria were used [17].

\section{Enzyme-linked immunosorbent assay (ELISA)} Serum amphiregulin (Human Amphiregulin ELISA kit catalog number: 201-12-3148 Shanghai Sunred Biological Technology, Shanghai, China) and cerebellin 1 (Human Cerebellin1 ELISA kit; catalog number: 201-12-3438 Shanghai Sunred Biological Technology, Shanghai, China) levels were measured using enzyme-linked immunosorbent assay method according to the manufacturer's protocol. Specimen absorbance values were determined on Multiskan FC microplate reader (Thermo Fisher Scientific) at a wavelength of $450 \mathrm{~nm}$. Values were expressed as picogram $/ \mathrm{mL}$. The intra-assay coefficient of variance $(\mathrm{CV})$, inter-assay $\mathrm{CV}$, detection range and sensitivity of the amphiregulin kit were reported as $<10 \%$, $<12 \%$, and $4-1000 \mathrm{pg} / \mathrm{mL}$ and $3.747 \mathrm{pg} / \mathrm{mL}$, respectively. The intra-assay CV, inter-assay CV, detection range and sensitivity of the cerebellin-1 kit were reported as $<11 \%,<12 \%$, and $5-1500 \mathrm{pg} / \mathrm{mL}$ and $4.385 \mathrm{pg} / \mathrm{mL}$, respectively.

\section{Statistical analysis}

Data management and analysis were performed using the SPSS program version 14 (SPSS Inc., Chicago, IL) and a two-sided $p$-value $\leq 0.05$ was considered statistically significant. Continuous data were expressed as mean \pm standard deviation or median, and categorical data as percentages. Means were compared via an independent sample $t$ test, and if there was no normal distribution, via a Mann-Whitney $\mathrm{U}$ test with median. Categorical data were evaluated using the chi square test as appropriate. The relationships between variables were assessed with Pearson correlation coefficient for normally distributed vari- ables and by Spearman's rank correlation coefficient for non-normally distributed variables. A receiver operator characteristic (ROC) curve analysis was performed to identify the optimal cut-off point of serum amphiregulin and levels for the prediction of hypertension. MedCalc (v. 12.7.8) was used to perform ROC curve analysis. The area under the curve (AUC) with 95\% confidence interval was calculated. The optimal cut-off value of serum amphiregulin level was defined as the value associated with the highest sum of sensitivity and specificity-1. We used univariate analysis to quantify the association of variables with hypertension. The variables found to be statistically significant in the univariate analysis and other potential confounders were used in multivariate logistic regression model with backward stepwise method in order to determine the independent prognostic factors of hypertension

\section{Results}

Clinical, laboratory and echocardiographic data of two groups were shown in Table 1 . There was no significant difference between groups regarding age and sex. Systolic pressure in hypertensive group was $165 \pm 5 \mathrm{~mm} \mathrm{Hg}$ and in control group was $117 \pm$ $12 \mathrm{~mm} \mathrm{Hg}(\mathrm{p}<0.001)$. Diastolic pressure in hypertensive group was $98 \pm 7 \mathrm{~mm} \mathrm{Hg}$ and in control group was $77 \pm 6 \mathrm{~mm} \mathrm{Hg}(\mathrm{p}<0.001)$. There were significant differences between the two groups in terms of amphiregulin, blood urea nitrogen (BUN) and potassium levels. Mean amphiregulin level was $32.1(10.2-72.5) \mathrm{pg} / \mathrm{mL}$ in hypertension group and $36.9(15.9-109.5) \mathrm{pg} / \mathrm{mL}$ in control group. Amphiregulin level was significantly lower in hypertensive group $(\mathrm{p}=0.002)$. Mean cerebellin 1 levels were 82.1 (23.9-286.1) pg/mL in hypertensive group and $95.1(60.2-293) \mathrm{pg} / \mathrm{mL}$ in control group. Cerebellin 1 levels were similar in hypertension and control groups $(p=0.26)$. There was not any correlation between systolic pressure, diastolic pressure and serum amphiregulin levels in hypertensive patients. Serum amphiregulin was correlated only with serum creatinine levels $(\mathrm{r}=0.25, \mathrm{p}=0.03)$. Serum BUN levels were $26.8 \pm 8.2 \mathrm{pg} / \mathrm{mL}$ in hypertension group and $16.4 \pm 4.8 \mathrm{pg} / \mathrm{mL}$ in control group $(\mathrm{p}=0.001)$. Serum potassium level was $4.6 \pm 0.4 \mathrm{mg} / \mathrm{dL}$ in hypertension group and $4.3 \pm 0.2 \mathrm{mg} / \mathrm{dL}$ in control group $(\mathrm{p}=0.001)$. Standard echocardiographic and other laboratory parameters were similar between two groups.

Optimal cut-off levels of serum amphiregulin to predict hypertension was found to be $\leq 23 \mathrm{pg} / \mathrm{mL}$ with specificity of $97 \%$ and sensitivity of $48.5 \%$ 
Table 1. Baseline characteristics of study patients

\begin{tabular}{|c|c|c|c|}
\hline Parameter & Hypertensive & Control & $p$ value \\
\hline \multicolumn{4}{|l|}{ Baseline characteristics } \\
\hline Age [y] & $49.4 \pm 11$ & $48 \pm 10$ & 0.622 \\
\hline Male/female, $n$ & $21 / 23$ & $22 / 24$ & 0.831 \\
\hline $\begin{array}{l}\mathrm{SBP}[\mathrm{mm} \mathrm{Hg}] \\
(\text { mean } \pm \mathrm{SD})\end{array}$ & $165 \pm 5$ & $117 \pm 12$ & $<0.001$ \\
\hline $\begin{array}{l}\mathrm{DBP}[\mathrm{mm} \mathrm{Hg}] \\
(\text { mean } \pm \mathrm{SD})\end{array}$ & $98 \pm 7$ & $77 \pm 6$ & $<0.001$ \\
\hline \multicolumn{4}{|l|}{ Laboratory findings } \\
\hline $\begin{array}{l}\text { Sodium [mg/dL] } \\
\text { (mean } \pm \text { SD) }\end{array}$ & $141.5 \pm 3.8$ & $140.5 \pm 3.0$ & 0.158 \\
\hline $\begin{array}{l}\text { Potassium [mg/dL] } \\
\text { (mean } \pm \text { SD) }\end{array}$ & $4.6 \pm 0.4$ & $4.3 \pm 0.2$ & 0.001 \\
\hline $\begin{array}{l}\text { Creatinine }[\mathrm{mg} / \mathrm{dL}] \\
(\text { mean } \pm \text { SD) }\end{array}$ & $0.7 \pm 0.2$ & $0.7 \pm 0.1$ & 0.101 \\
\hline $\begin{array}{l}\text { BUN [mg/dL] } \\
\text { (mean } \pm \text { SD) }\end{array}$ & $26.8 \pm 8.2$ & $16.4 \pm 4.8$ & $<0.001$ \\
\hline $\begin{array}{l}\text { Chloride } \\
\text { [mg/dL] } \\
\text { (mean } \pm \text { SD) }\end{array}$ & $103 \pm 5$ & $102 \pm 4$ & 0.308 \\
\hline $\begin{array}{l}\text { Calcium [mg/dL] } \\
\text { (mean } \pm \text { SD) }\end{array}$ & $9.67 \pm 0.5$ & $10 \pm 0.1$ & 0.495 \\
\hline $\begin{array}{l}\text { AST [U/L] } \\
\text { (mean } \pm \text { SD) }\end{array}$ & $21 \pm 6.1$ & $23.7 \pm 8$ & 0.085 \\
\hline $\begin{array}{l}\mathrm{ALT}[\mathrm{U} / \mathrm{L}] \\
(\text { mean } \pm \mathrm{SD})\end{array}$ & $20 \pm 9$ & $22 \pm 11$ & 0.318 \\
\hline $\begin{array}{l}\text { Blood glucose [mg/dL] } \\
\text { (mean } \pm \text { SD) }\end{array}$ & $102 \pm 23$ & $97 \pm 13$ & 0.359 \\
\hline $\begin{array}{l}\text { MPV [fL] } \\
\text { (mean } \pm \text { SD) }\end{array}$ & $10.4 \pm 0.8$ & $9.9 \pm 1.7$ & 0.173 \\
\hline $\begin{array}{l}\text { PIt }\left[10^{3} / \mathrm{mm}^{3}\right] \\
\text { (mean } \pm \text { SD) }\end{array}$ & $262 \pm 70$ & $240 \pm 63$ & 0.162 \\
\hline $\begin{array}{l}\mathrm{Hb}[\mathrm{g} / \mathrm{dL}] \\
(\text { mean } \pm \mathrm{SD})\end{array}$ & $14.2 \pm 1.7$ & $13.8 \pm 1.8$ & 0.392 \\
\hline $\begin{array}{l}\mathrm{HCT}(\%) \\
(\text { mean } \pm \text { SD) }\end{array}$ & $41.1 \pm 4.5$ & $42.4 \pm 4.3$ & 0.212 \\
\hline $\begin{array}{l}\text { WBC }\left[10^{3} \mathrm{~mm}^{3}\right] \\
(\text { mean } \pm \mathrm{SD})\end{array}$ & $8.0 \pm 1.7$ & $8.3 \pm 2.4$ & 0.325 \\
\hline $\begin{array}{l}\mathrm{RBC}\left[10^{6} \mathrm{U} / \mathrm{L}\right] \\
\text { (mean } \pm \mathrm{SD} \text { ) }\end{array}$ & $5.0 \pm 0.6$ & $4.9 \pm 0.3$ & 0.452 \\
\hline $\begin{array}{l}\text { Amphiregulin [pg/mL] } \\
\text { [median (IQR)] }\end{array}$ & $32.1(10.2-72.5)$ & $36.9(15.9-109.4)$ & 0.002 \\
\hline $\begin{array}{l}\text { Cerebellin [pg/mL] } \\
\text { [median (IOR)] }\end{array}$ & $82.1(23.9-286.1)$ & $95.1(60.2-293)$ & 0.261 \\
\hline \multicolumn{4}{|c|}{ Echocardiographic findings } \\
\hline $\begin{array}{l}\text { Mitral E velocity }[\mathrm{cm} / \mathrm{s}] \\
\text { (mean } \pm \text { SD) }\end{array}$ & $87.5 \pm 9.3$ & $91 \pm 14.4$ & 0.175 \\
\hline $\begin{array}{l}\text { Mitral A velocity }[\mathrm{cm} / \mathrm{s}] \\
(\text { mean } \pm \mathrm{SD})\end{array}$ & $62.4 \pm 10.5$ & $66 \pm 14.5$ & 0.185 \\
\hline E/A ratio & $1.4 \pm 0.2$ & $1.5 \pm 0.2$ & 0.489 \\
\hline
\end{tabular}


Table 1. Baseline characteristics of study patients

\begin{tabular}{|l|c|c|c|}
\hline Parameter & Hypertensive & Control & p value \\
\hline $\begin{array}{l}\text { DT [ms] } \\
\text { (mean } \pm \text { SD) }\end{array}$ & $187.7 \pm 9.8$ & $188 \pm 12.7$ & 0.689 \\
\hline $\begin{array}{l}\text { IVRT [ms] } \\
\text { (mean } \pm \text { SD) }\end{array}$ & $87.6 \pm 3$ & $84.4 \pm 14$ & 0.107 \\
\hline $\begin{array}{l}\text { LVEF (\%) } \\
\text { (mean } \pm \text { SD) }\end{array}$ & $66 \pm 5$ & $68 \pm 5$ & 0.071 \\
\hline $\begin{array}{l}\text { Septum thickness [mm] } \\
\text { (mean } \pm \text { SD) }\end{array}$ & $9.6 \pm 1.2$ & $9.2 \pm 1.10$ & 0.133 \\
\hline $\begin{array}{l}\text { Posterior wall thickness [mm] } \\
\text { (mean } \pm \text { SD) }\end{array}$ & $8.8 \pm 3.4$ & $8.0 \pm 1$ & 0.88 \\
\hline $\begin{array}{l}\text { Left atrial diameter [cm] } \\
\text { (mean } \pm \text { SD) }\end{array}$ & $34 \pm 3.6$ & $34 \pm 2.2$ & \\
\hline
\end{tabular}

SBP — systolic blood pressure; DBP — diastolic blood pressure; BUN — blood urea nitrogen; AST — aspartate aminotransferase; ALT — alanine aminotransferase; MPV — mean platelet volume; PLT — platelet; $\mathrm{Hb}$ - hemoglobin; HCT — hematocrit; WBC — white blood cell; RBC — red blood cell; DT — deceleration time; IVRT — isovolumetric relaxation time; LVEF — left ventricle ejection fraction; SD — standard deviation; IQR — interquartile range

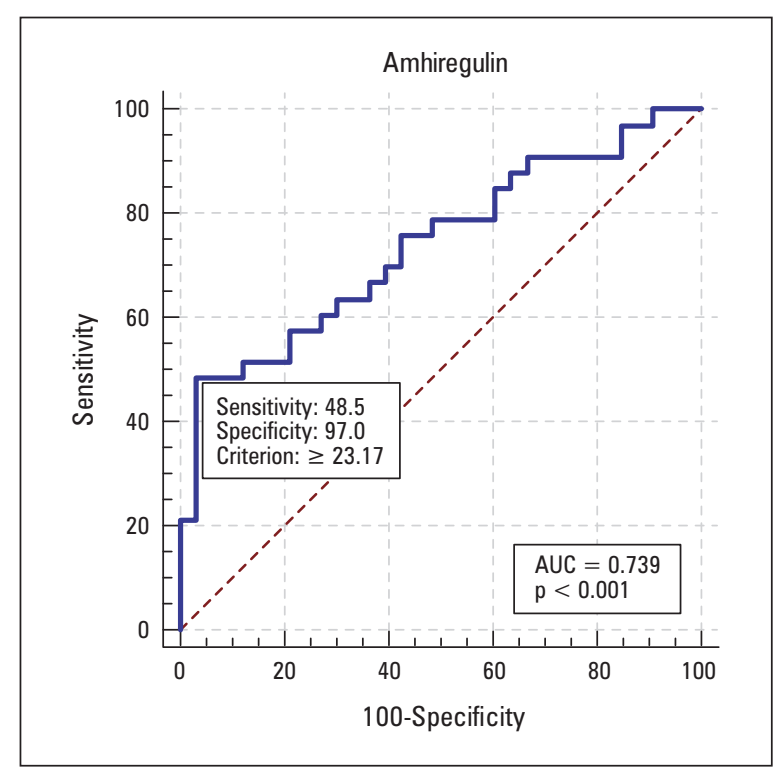

Figure 2. Receiver operating characteristic (ROC) curve analysis of amphiregulin to predict hypertension
$[$ AUC $=0.74 ; 95 \%$ confidence interval $(\mathrm{CI})$ : 0.62-0.86; $\mathrm{p}=0.001$ ] (Fig. 2).

In the multiple logistic regression model, serum amphiregulin levels [odd ratio $(\mathrm{OR})=1.04,95 \% \mathrm{CI}$ : $1.01-1.18, \mathrm{p}=0.02]$ and $\mathrm{BUN}(\mathrm{OR}=1.10,95 \%$ CI: $1.02-1.18, p=0.01$ ) were associated with hypertension after adjusting for the confounding variables, which were either found to be statistically significant in the univariate analysis and for the variables correlated with serum amphiregulin levels (Tab. 2).

\section{Discussion}

To the best of our knowledge, this study is the first to investigate amphiregulin and cerebellin 1 in hypertensive patients. It was revealed in this study that amphiregulin levels were low in newly diagnosed hypertension patients and low amphiregulin level was an independent predictor of newly diagnosed

Table 2. Univariate and multivariate analyses for predicting hypertension

\begin{tabular}{|l|c|c|c|c|}
\hline Variable & \multicolumn{2}{|c|}{ Univariate } & \multicolumn{2}{c|}{ Multivariate } \\
\hline & $\mathbf{p}$ & $\begin{array}{c}\text { OR } \\
(95 \% \mathrm{CI})\end{array}$ & $\begin{array}{c}\text { OR } \\
(95 \% \mathrm{CI})\end{array}$ \\
\hline Amphiregulin & 0.005 & $1.047(1.014-1.081)$ & 0.022 & $1.042(1.006-1.079)$ \\
\hline BUN & $<0.001$ & $1.121(1.055-1.190)$ & 0.014 & $1.095(1.018-1.178)$ \\
\hline Potassium & 0.057 & $3.076(0.969-9.769)$ & & \\
\hline Variables which correlated with amphiregulin & & & \\
\hline Creatinine & 0.099 & $7.827(0.679-90.217)$ & & \\
\hline
\end{tabular}

All the variables from Table 1 were examined and only those significant at $p<0.05$ level and correlated with amphiregulin are shown in univariate analysis. Multivariate logistic regression analysis including all the variables in univariate analysis with enter method. $\mathrm{Cl}$ — confidence interval; $\mathrm{OR}$ - odds ratio; BUN — blood urea nitrogen 
hypertension. It was found that cerebellin levels did not differ between the healthy group and the newly diagnosed hypertensive group. We also showed that serum urea level is high in hypertensive group and urea levels are associated with hypertension de novo.

Many studies have shown that EGF is associated with vascular diseases such as atherosclerosis and hypertension through epidermal growth factor receptor (EGFR). The EGFR is expressed in vascular smooth muscle cells, endothelial cells, macrophages and regulatory $\mathrm{T}$ lymphocytes, and all of these cells also secrete EGFR ligands [5]. Preventive effect of EGFR on excessive hypertrophic growth of cardiomyocytes and contribution of EGFR to the appropriate vascular wall architecture and vessel reactivity have been shown. With these effects EGF has roles supporting a physiological vascular tone and is also required for physiological cardiovascular tissue homeostasis [18]. Transactivation of EGF/ /EGFR reported to cause vasoconstriction [19]. In human studies plasma EGF levels were found to be correlated with diastolic blood pressure and carotid artery stiffness [20]. In an experimental study, an EGFR inhibitor, erlotinib failed to reduce elevated blood pressure in angiotensin II infused mice but protected animals from perivascular fibrosis [21]. Epidermal growth factor and its receptor are widely expressed in kidney and modulate glomerular hemodynamics and renal metabolism. Epidermal growth factor and its signaling involve in cell growth, proliferation, and renal electrolyte homeostasis. Activation of EGFR plays role in renal hemodynamics and electrolyte metabolism in kidney under physiological conditions [22]. Epidermal growth factor induces constriction of both preglomerular and postglomerular arterioles and reduces glomerular filtration and perfusion that may cause hypertensive effect. On the other hand, intravenous infusion of EGF for several days decreased the epithelial sodium channel activity, prevented the development of hypertension and attenuated renal glomerular and tubular damage in an experimental study [23]. Epidermal growth factor and EGF ligands such as amphiregulin are expected to be high in hypertensive patients. Contrary to our expectations serum amphiregulin levels were lower in hypertensive patients than controls in our study. When analyzed with the data in the literature, amphiregulin may have complex roles in the pathogenesis of hypertension. Amphiregulin may cause different effects in pathological and physiological processes as EGF and EGFR discussed in the above articles. Rather than activator roles amphiregulin may have regulatory functions in blood pressure. The patients in our study group were hypertensive and were not taking any antihypertensive drugs. Amphiregulin levels in these patients may have been found to be low in order to reduce vasoconstriction in vascular smooth muscle due to the body's compensation mechanisms. On the other hand, the vasoconstrictor effects of amphiregulin on glomerular precapillary and post-capillary arterioles may have been tried to be compensated by reducing the release of amphiregulin in hypertensive patients. Perhaps the primary cause of the hypertension in these patients may be due to a mutation in the amphiregulin gene or the amount of amphiregulin may not be released enough to balance the vascular tone. More comprehensive and large-scale studies are needed to clarify the exact mechanism.

The early stage of primary hypertensive kidney involvement is characterized by afferent arteriolar vasoconstriction. Thus, renal blood flow and effective renal plasma flow (ERPF) are reduced, glomerular filtration rate (GFR) is maintained within relatively normal limits and filtration fraction (GFR/ERPF) increases $[24,25]$. Microproteinuria occurs due to the increase in the filtration fraction. Microproteinuria is responsible for the onset and progression of tubulointerstitial injury $[24,26]$. A decrease in renal blood flow reduces tubular urea secretion. Excessive absorption of sodium and water from the proximal tubules increases post-secretory urea absorption. Therefore, an increase in serum urea level may occur [27]. Since these hemodynamic events are potentially reversible, it is very important to detect kidney involvement at an early stage. We revealed in this study that the blood urea levels of newly diagnosed hypertension patients were high. In addition, high blood urea values were an independent variable for hypertension. Because blood urea levels are affected by many pathologies, it may not be appropriate to use this parameter in the first diagnosis of primary hypertension.

Investigations about the effects of cerebellin on circulation are very limited. Rucinski et al. demonstrated that cerebellin-derived peptides have adrenocorticotropic hormone (ACTH)-like effects on corticosterone output and proliferative activity of cultured rat adrenocortical cells [28]. Previous studies showed that cerebellin is a potent stimulator of direct norepinephrine release by rat adrenal medulla and enhances adrenocortical steroid secretion. Adrenocortical secretagogue effect of cerebellin is mediated by locally released catecholamines that act on the cortex in a paracrine manner [29, 30]. Gauli et al. reported that autonomous aldosterone secretion is more prevalent among patients with primary hypertension and significantly correlated with systolic 
and diastolic arterial blood pressure [31]. Cerebellin increases norepinephrine release from the adrenal medulla. Previous studies have shown a relationship between hypertension and sympathetic system activation. Before starting the study we hypothesized that the increase of sympathetic activity in hypertensive patients may be caused by high cerebellin levels. However, cerebellin-1 levels were lower in hypertensive patients than in the control group, without statistical significance.

In another study, we compared the serum amphiregulin and cerebellin 1 levels of severe preeclampsia patients with healthy pregnant women and healthy normotensive nonpregnant women control subjects. We found significantly decreased serum amphiregulin and cerebellin 1 levels in severe preeclampsia patients compared with healthy pregnant women and controls [32]. Serum amphiregulin was also lower in patients with hypertension in current study. Serum cerebellin levels were similar in hypertensive and healthy individuals, contrary to our expectations. As it is known, compared to primary hypertension, preeclampsia is a more acute and rapidly progressing pathology. Hypothetically rapid and appropriate cerebellin secretion response may not occur in preeclampsia patients compared to those of primary hypertension patients.

Our study has some limitations. If we studied aforementioned molecules such as norepinephrine and aldosterone that contributes to the pathogenesis of hypertension in combination with amphiregulin and cerebellin 1, we would have achieved more precise results. According to the results of our study, serum amphiregulin indicate the presence of hypertension rather than its severity.

In conclusion, serum amphiregulin appears to be lower in primary hypertension patients when compared to normotensives. Low amphiregulin $(\leq 23 \mathrm{pg} / \mathrm{mL})$ can be used to support the diagnosis of primary hypertension.

\section{Financial support}

No financial support was received for this submission.

\section{Conflict of interest}

The authors declare that they have no conflict of interest.

\section{References}

1. Lawes C, Hoorn S, Rodgers A. Global burden of blood-pressure-related disease, 2001. Lancet. 2008; 371(9623): 15131518, doi: 10.1016/s0140-6736(08)60655-8, indexed in Pubmed: 18456100.
2. Singh M, Singh AK, Pandey P, et al. Molecular genetics of essential hypertension. Clin Exp Hypertens. 2016; 38(3): 268-277, doi: 10. 3109/10641963.2015.1116543, indexed in Pubmed: 27028574.

3. Pierdomenico SD, Di Nicola M, Esposito AL, et al. Prognostic value of different indices of blood pressure variability in hypertensive patients. Am J Hypertens. 2009; 22(8): 842-847, doi: 10.1038/ ajh.2009.103, indexed in Pubmed: 19498342.

4. Staruschenko A, Palygin O, Ilatovskaya DV, et al. Epidermal growth factors in the kidney and relationship to hypertension. Am J Physiol Renal Physiol. 2013; 305(1): F12-F20, doi: 10.1152/ ajprenal.00112.2013, indexed in Pubmed: 23637204.

5. Schreier B, Gekle M, Grossmann C. Role of epidermal growth factor receptor in vascular structure and function. Curr Opin Nephrol Hypertens. 2014; 23(2): 113-121, doi: 10.1097/01. mnh.0000441152.62943.29, indexed in Pubmed: 24401788.

6. Makki N, Thiel KW, Miller FJ. The epidermal growth factor receptor and its ligands in cardiovascular disease. Int J Mol Sci. 2013; 14(10): 20597-20613, doi: 10.3390/ijms141020597, indexed in Pubmed: 24132149 .

7. Berasain C, Avila MA. Amphiregulin. Semin Cell Dev Biol. 2014; 28: 31-41, doi: 10.1016/j.semcdb.2014.01.005, indexed in Pubmed: 24463227.

8. Seigneur E, Südhof TC. Cerebellins are differentially expressed in selective subsets of neurons throughout the brain. J Comp Neurol. 2017; 525(15): 3286-3311, doi: 10.1002/cne.24278, indexed in Pubmed: 28714144 .

9. Mazzocchi G, Andreis PG, De Caro R, et al. Cerebellin enhances in vitro secretory activity of human adrenal gland. J Clin Endocrinol Metab. 1999; 84(2): 632-635, doi: 10.1210/jcem.84.2.5462, indexed in Pubmed: 10022429.

10. Rucinski M, Ziolkowska A, Szyszka M, et al. Precerebellin-related genes and precerebellin 1 peptide in endocrine glands of the rat pattern of their expression. Int J Mol Med. 2009; 23(1): 113-119, indexed in Pubmed: 19082514.

11. Strowski MZ, Kaczmarek P, Mergler S, et al. Insulinostatic activity of cerebellin--evidence from in vivo and in vitro studies in rats. Regul Pept. 2009; 157(1-3): 19-24, doi: 10.1016/j.regpep.2009.05.010, indexed in Pubmed: 19481574.

12. Satoh F, Takahashi K, Murakami O, et al. Cerebellin and cerebellin mRNA in the human brain, adrenal glands and the tumour tissues of adrenal tumour, ganglioneuroblastoma and neuroblastoma. J Endocrinol. 1997; 154(1): 27-34, doi: 10.1677/joe.0.1540027, indexed in Pubmed: 9246935.

13. Aydin S. Can cerebellin and renalase measurements contribute to the elimination of false positive results in pheochromocytoma and paraganglioma diagnoses? Med Hypotheses. 2017; 107: 64, doi: 10.1016/j.mehy.2017.07.025, indexed in Pubmed: 28915965.

14. Whelton PK, Carey RM, Aronow WS, et al. 2017 ACC/AHA/AAPA/ ABC/ACPM/AGS/APhA/ASH/ASPC/NMA/PCNA Guideline for the Prevention, Detection, Evaluation, and Management of High Blood Pressure in Adults: A Report of the American College of Cardiology/American Heart Association Task Force on Clinical Practice Guidelines. Circulation. 2018; 138(17): e484-e594, doi: 10.1161/ CIR.0000000000000596, indexed in Pubmed: 30354654.

15. McCormack T, Boffa RJ, Jones NR, et al. The 2018 ESC/ESH hypertension guideline and the 2019 NICE hypertension guideline, how and why they differ. Eur Heart J. 2019; 40(42): 3456-3458, doi: 10.1093/eurheartj/ehz681, indexed in Pubmed: 31589745.

16. Güneş H, Alkan Baylan F, Güneş H, et al. Can Nesfatin-1 Predict Hypertension in Obese Children? J Clin Res Pediatr Endocrinol. 2020; 12(1): 29-36, doi: 10.4274/jcrpe.galenos.2019.2019.0072, indexed in Pubmed: 31339256.

17. Temiz F, Güneş H, Güneş H. Evaluation of Atrial Electromechanical Delay in Children with Obesity. Medicina (Kaunas). 2019; 55(6), doi: 10.3390/medicina55060228, indexed in Pubmed: 31151287.

18. Schreier B, Rabe S, Schneider B, et al. Loss of epidermal growth factor receptor in vascular smooth muscle cells and cardiomyocytes causes arterial hypotension and cardiac hypertrophy. Hypertension. 2013; 61(2): 333-340, doi: 10.1161/HYPERTENSIONAHA.112.196543, indexed in Pubmed: 23248150. 
19. Fernandez-Patron C. Therapeutic potential of the epidermal growth factor receptor transactivation in hypertension: a convergent signaling pathway of vascular tone, oxidative stress, and hypertrophic growth downstream of vasoactive G-protein-coupled receptors? Can J Physiol Pharmacol. 2007; 85(1): 97-104, doi: 10.1139/y06-097, indexed in Pubmed: 17487249.

20. Lundstam U, Hägg U, Sverrisdottir YB, et al. Epidermal growth factor levels are related to diastolic blood pressure and carotid artery stiffness. Scand Cardiovasc J. 2007; 41(5): 308-312, doi: 10.1080/14017430701439508, indexed in Pubmed: 17852780.

21. Takayanagi T, Kawai T, Forrester SJ, et al. Role of epidermal growth factor receptor and endoplasmic reticulum stress in vascular remodeling induced by angiotensin II. Hypertension. 2015; 65(6): 1349-1355, doi: 10.1161/HYPERTENSIONAHA.115.05344, indexed in Pubmed: 25916723.

22. Zeng F, Singh AB, Harris RC. The role of the EGF family of ligands and receptors in renal development, physiology and pathophysiology. Exp Cell Res. 2009; 315(4): 602-610, doi: 10.1016/j. yexcr.2008.08.005, indexed in Pubmed: 18761338.

23. Pavlov TS, Levchenko V, O'Connor PM, et al. Deficiency of renal cortical EGF increases ENaC activity and contributes to saltsensitive hypertension. J Am Soc Nephrol. 2013; 24(7): 1053-1062, doi: 10.1681/ASN.2012080839, indexed in Pubmed: 23599382.

24. Bauer JH, Reams GP, Wu Z. The aging hypertensive kidney: pathophysiology and therapeutic options. Am J Med. 1991; 90(4B): 21S-27S, doi: 10.1016/0002-9343(91)90475-d, indexed in Pubmed: 2018052

25. Schwartz GL, Strong CG. Renal parenchymal involvement in essential hypertension. Med Clin North Am. 1987; 71(5): 843-858, doi: 10.1016/s0025-7125(16)30812-4, indexed in Pubmed: 3306206
26. Giaconi S, Levanti C, Fommei E, et al. Microalbuminuria and casual and ambulatory blood pressure monitoring in normotensives and in patients with borderline and mild essential hypertension. Am J Hypertens. 1989; 2(4): 259-261, doi: 10.1093/ajh/2.4.259, indexed in Pubmed: 2706093.

27. Ateș K, Ertuğ E, Arıcan A, et al. Microproteinuria and Serum Uric Acid Levels as Early Markers of Renal Involvement in Essential Hypertension. Ankara Tip Mecmuası (J Faculty Med). 1994; 47: 433-446.

28. Rucinski M, Ziolkowska A, Szyszka M, et al. Cerebellin and descerebellin exert ACTH-like effects on corticosterone secretion and the intracellular signaling pathway gene expression in cultured rat adrenocortical cells--DNA microarray and QPCR studies. Int J Mol Med. 2009; 23(4): 539-546, doi: 10.3892/ijmm_00000162, indexed in Pubmed: 19288031.

29. Albertin G, Malendowicz LK, Macchi C, et al. Cerebellin stimulates the secretory activity of the rat adrenal gland: in vitro and in vivo studies. Neuropeptides. 2000; 34(1): 7-11, doi: 10.1054/ npep.1999.0779, indexed in Pubmed: 10688962.

30. Hochól A, Neri G, Majchrzak M, et al. Prolonged cerebellin administration inhibits the growth, but enhances steroidogenic capacity of rat adrenal cortex. Endocr Res. 2001; 27(1-2): 11-17, doi: 10.1081/ erc-100107164, indexed in Pubmed: 11428704.

31. Gouli A, Kaltsas G, Tzonou A, et al. High prevalence of autonomous aldosterone secretion among patients with essential hypertension. Eur J Clin Invest. 2011; 41(11): 1227-1236, doi: 10.1111/j.13652362.2011.02531.x, indexed in Pubmed: 21534948.

32. Güler Ö, Özer A, Seyithanoğlu M, et al. Serum amphiregulin and cerebellin-1 levels in severe preeclampsia. J Matern Fetal Neonatal Med. 2019 [Epub ahead of print]: 1-6, doi: 10.1080/14767058.2 019.1671345, indexed in Pubmed: 31630583. 